\title{
Teori Telapak Kaki Bj Habibie untuk Kota Parepare
}

Suhartina

\section{PENDAHULUAN}

\section{A. Latar Belakang}

Kota parepare adalah salah satu dari Kotamadya yang ada di Sulawesi Selatan. Letaknya tepat di antara kota Barru, Pinrang, dan Sidrap. Berbeda dengan kota lain yang ada di Sulawesi Selatan, hampir bisa dikatakan Kota Parepare, tidak memiliki sumber daya alam yang melimpah. Meskipun begitu, Kota Parepare terbukti menjadi salah satu Kota yang memiliki perkembangan ekonomi yang meningkat dari tahun ke tahun. Hal tersebut tentu tak lepas dari kinerja Wali Kota Parepare yang menjadikan Kota Parepare sebagai kota yang patut untuk diperhitungkan.

Kota Parepare, selain terkenal sebagai kota Madani, juga lekat dengan julukan Kota Kelahiran Presiden Ketiga, Prof.Dr.Ing. Bj. Habibie. Julukan ini, tentulah bukan hanya sekadar julukan dan kebanggaan bagi masyarakt Parepare. Namun, juga dijadikan sebagai pemantik datangnya berbagai pihak ke Kota Parepare. Sehingga membuat Kota Parepare tidak hanya terkenal, tetapi juga menambah pundi-pundi ekonomi Kota Parepare. Sebut saja, pembangunan patung Habibi Ainun di Lapangan Andi Makkasau. Dengan hadirnya patung tersebut, banyak masyarakat, atau pun wisatawan yang datang berfoto- foto di sana. Hal tersbut menambah penghasilan masyarakt sekitar.

Lahirnya presiden ketiga di Parepare, tentulah sebuah anugrah tersendiri bagi masyarakat. Namun, tanpa ide brilian dari Walikota Parepare, Bapak Dr.H.M.Taufan Pawe, SH.,MH. anugrah tersebut tentu tidak akan bisa dimaksimalkan dengan baik. Bapak H.M.Taufan Pawe, melihat peluang Telapak Kaki sebagai sebuah peluang untuk menjadikan kota Parepare sebagai kota yang maju. Beliau pulalah yang pertama kali memprakarsai Teori Telapak Kaki.

\section{B. Rumusan Masalah}

1. Apa yang dimaksud teori telapak kaki?

2. Apa pengaruh telapak kak BJ Habibie terhadap kota Parepare?

\section{Tujuan}

1. Untuk mendeskripsikan teori telapak kaki

2. Apa pengaruh telapak kaki BJ Habibie terhadap kota Parepare 


\section{PEMBAHASAN}

\section{A. Teori Telapak Kaki}

Teori telapak kaki, diprakarsai oleh walikota Parepare,Dr.H.M. Taufan Pawe,SH.,MH. Teori ini menjelaskan tentang pengaruh telapak kaki BJ. Habibie, yang mengundang telapak-telapak kaki yang lain, untuk datang ke kota Parepare. Telapak kaki pada hakikatnya diartikan sebagai pijakan kaki. Secara umum dapat diartikan sebagai kehadiran seseorang pada wilayah/ daerah tertentu yang meninggalkan jejak.

Sebagai Walikota Parepare dua periode, bapak Dr.H.M. Taufan Pawe,S.H, M.H telah banyak memberikan kontribusi yang signifikan terhadap perkembangan kota Parepare. Peningkatan infrasruktur menjadi salah satu tolok ukur kemajuan kota Parepare yang tentu berimbas pada aspek ekonomi sebuah wilayah.

Dalam salah satu wawancara, Wali Kota Parepare tersebut mengatakan bahwa “ "Salah satu indikator untuk melihat pembangunan adalah pertumbuhan ekonomi. Pertumbuhan ekonomi yang positif menunjukkan adanya peningkatan aktivitas perekonomian, sebaliknya pertumbuhan ekonomi yang negatif menunjukkan adanya penurunan dalam aktivitas perekonomian",",

Tentu bukan lagi rahasia umum, begitu banyak infrastruktur yang telah beliau hadirkan di kota Parepare yang memberikan dampak ekonomi terhadap kota Parepare, seperti Kebun Raya Jompie, Patung Habibie- Ainun, Jembatan Tonrangeng River Side, penataan ulang Pasar Rakyat Sumpang Minangae, serta Penataan Pasar Senggol serta Kawasan Hastom. Dua infrastruktur yang terakhir sementara berada pada masa pemantauan kembali. Infrakstruktur tersebut merupakan jalur menuju Rumah Sakit dr Asri Ainun, yang sementara dibangun. Jembatan Tonrangen River Side ini diharapkan tida hanya dapat menarik wisatawan/ pengunjung dengan pemandangan, tetapi juga kulinernya. Sehingga Wali Kota Parepare akan membangun tempat-tempat kuliner dan pembangunan lainnya di area jembatan Tonrangeng River Side. Begitu pun dengan Pasar Rakyat Sumpang Minangae.

\footnotetext{
${ }^{1}$ Muliadi, “Taufan Pawe: Parepare Siap Jadi Kota Metropolis”,tribun timur, diterbitkan online pada tangal 21 Februari 2019, https://makassar.tribunnews.com
} 
Meskipun, pasar tersebut sudah menjadi tren masyarakat Parepare, tetapi Walikotra Parepare membenahinya menjadi lebih berkelas, karena akan menambah daya tarik masyarakat untuk ke sana.

\section{B. Pengaruh Bj. Habibie Terhadap Kota Parepare}

Bacharuddin Jusuf Habibie, FREng lahir di Parepare, Sulawesi Selatan, 25 Juni 1936. Beliau memang tidak lama berada di Kota Parepare, karena beliau dan keluarganya pindah ke Bandung. Namun, kehadiran Habibie di Kota Parepare tentu memberikan warna tersendiri untuk Kota Parepare, setelah beliau menjadi Presiden R.I. Segala seluk beluk beliau pun dieskpos, termasuk kehidupan masa kecilnya. Kota Parepare tentu menjadi bagian dari sejarah beliau, sebagai tempat lahir seorang pria berintelektual luar biasa yang akhirnya menjadi presiden RI.

Kehadiran Habibie sebagai tokoh bersejarah di Indonesia, dan Parepare khususnya, memberikan dampak yang positif, tidak hanya menjadikan Parepare dikenal dunia. Namun, juga memberi dampak pada aspek ekonomi. Nama Habibie oleh Wali Kota Parepare dijadikan dasar sebagai peluang perkembangan dan kemajuan Kota Parepare. Wali Kota Parepare menerapkan Teori Telapak Kaki Bj. Habibie dalam mewujudkan Kota Parepare yang maju.

Patung Habibie Ainun, Gedung Balai Ainun, Institut Teknologi Habibie, Rumah Sakit Habibie Ainun adalah bangunan yang telah digagas dan didirikan pada masa pemerintahan Dr. H.M.Taufan Pawe, SH.,MH. Kehadiran Patung Habibie Ainun di Lapangan Andi Makkasau Parepare, menjadi salah satu spot foto yang diminati para wisatawan. Cinta Habibie Ainun tentu menjadi dekade kesetiaan cinta dua insan yang menjadikan patung tersebut diminati oleh kaum muda-mudi ataupun pasangan suami istri untuk berfose di sana. Kehadiran patung Habibie-Ainun pun mengobati kerinduan para pengagum presiden ketiga tersebut. Semakin banyaknya orang yang berkunjung ke sana, membuat sektor perekonomian masyarakat di sekitar pun meningkat.

Gedung Balai Ainun; gedung tersebut tidak hanya digunakan sebagai tempat pertemuan tetapi juga sebagai tempat penjualan kuliner khas Parepare. Ainun, sebagai seseorang yang mendampingi $\mathrm{Bj}$. Habibie dengan kesetiaannya tentu menjadi tokoh yang juga menarik perhatian dan kekaguman para wanita di Indonesia, khususnya Parepare. Sehingga patutlah jika gedung ini sering dimanfaatkan oleh organisasi-organisasi perempuan, misalnya Organisasi WI saat melaksanakan pertemuan. Digunakannya gedung ini sebagai 
pusat pertemuan secara tidak langsung menjadi tempat berkembangkanya sumber daya manusia masyarakat Parepare, sementar pusat kuliner dapat menambah perekonomian.

Di Parepare, terdapat beberapa perguruan tinggi, baik negeri maupun swasta. Kehadiran perguruan tinggi tentu bagian dari pemerataan sumber daya manusia. Pada tahun 2014 wali kota Parepare, mencanangkan pendirian Institut Teknologi Habibi. Institut Teknologi Habibi ini, tentulah akan menjadi Institut teknologi pertama di Sulawesi Selatan.

Dengan keberadaan kampus ini diharapkan juga dapat meningkatkan perekonomian ekonomi Parepare, dan Sulawesi Selatan pada umumnya, seperti pada bidang transportasi, perdagangan, dan perumahan.

Rumah sakit Hasri Ainun Habibie; membawa trend nama presiden ketiga RI, dan istrinya tentulah menjadi patron bahwa rumah sakit ini bukanlah rumah sakit biasa, seperti rumah sakit pada umumnya. Rumah sakit yang didirikan di kawasan Tonrangen River Side ini, diprogres menjadi rumah sakit rujukan, layaknya rumah sakit rujukan di Singapura. Rumah sakit ini, ditargetkan memiliki 1000 tempat tidur. Daya tarik lain dari rumah sakit ini adalah sebagai rumah sakit wisata, dengan letaknya yang sangat strategis.

Kehadiran Bj.Habibie di Kota Parepare memang memberikan banyak inspirasi dan motivasi di Kota Parepare, bahwa Parepare telah melahirkan sosok luar biasa. Hal tersebut juga menginspirasi Wali Kota Parepare untuk mendirikan Museum Bj. Habibie. Museum ini digadang-gadang akan berisi tentnag dokumentasi pesawat-pesawat y dibuat Habibie, desain pesawat, dan segala hal tentang Habibie. Sebagai museum Habibie satu-satunya di dunia, maka museum ini nantinya akan menjadi daya tarik bagi banyak wisatawan domestik, maupun mancanegara. Sehingga Parepare nantinya akan semakin dikenal dunia, dan tentu berkorelasi dengan pendapatan daerah. 


\section{PENUTUP}

\section{A. Simpulan}

1. Teori Telapak kaki dicanangkan oleh Wali Kota Parepare, Dr. H.M. Taufan Pawe,SH.,MH. Teori ini menjelaskan tentang pengaruh telapak kaki/ kehadiran tokoh yang berdampak pada meningkatnya kualitas sebuah daerah.

2. Lahirnya Presiden Ketiga RI, Prof.Dr.Ing.BJ Habibie di Kota Parepare yang memberikan dampak ekonomi dan kemajuan di Kota Parepare.

\section{B. Implikasi}

1. Makalah ini diharapkan menjadi salah satu tambahan kajian pengetahuan terutama untuk teori telapak kaki.

2. Teori Telapak Kaki dapat diterapkan secara maksimal, menuju Kota Parepare yang berjaya 


\section{DAFTAR PUSTAKA}

Mulyadi, “Taufan Pawe: Parepare Siap Jadi Kota Metropolis”, Tribun Timur, https//makassar.tribunnews.com.

Haramain, M. (2018). Dakwah dan Perdebatan Seputar Pluralisme.

Suhartina, S. (2017). Peningkatan Keterampilan Menulis Paragraf Deskriptif pada Siswa Kelas X4 SMA Negeri 3 Bulukumba. AL-ISHLAH: Jurnal Pendidikan Islam, 15(2), 130-146. 